\title{
THE REVISED ENLARGEMENT METHODOLOGY FOR THE WESTERN BALKANS ${ }^{\star *}$
}

The article examines the EU Commission's Communication of 5 February 2020 introducing a revised enlargement methodology for the purpose of reinvigorating the accession process of the Western Balkans candidate countries and make it more effective. Reasons put forward by some EU Member States at the end of 2019 for vetoing the opening of accession negotiations with Albania and North Macedonia are also discussed. The article suggests that the strategy outlined by the Council Conclusions of 5 June 2020 of enhancing cooperation with Western Balkans partners in the field of justice and home affairs (in particular, by strengthening cooperation with relevant EU Agencies) might be the key driving force for a more credible and dynamic EU perspective for the Western Balkans.

KEYWORDS: Western Balkans; EU Accession process; enlargement methodology; migration and security; EU agencies.

\section{THE WESTERN BALKANS AS A GEOSTRATEGIC INVESTMENT FOR THE EU AT TIMES OF HEIGHTENED GEOPOLITICAL COMPETITION}

Fundamental values enshrined in article 2 of the Treaty on European Union (TEU) are the most important reference for the enlargement policy. The accession of the Western Balkans to the EU is however a long and complex way to go due to foreseeable and unpredictable causes.

Among the foreseeable causes we can remember the legacy of past armed conflicts and the starting conditions of these neighbouring countries while among those unpredictable one should refer to some recent changes of the global geopolitical scenario such as, for

\footnotetext{
* PhD, Professor of Public International Law, Faculty of Law and Economics, Kore University of Enna, Email: paolo.bargiacchi@unikore.it.

** The paper is the result of research carried out by the author within the Jean Monnet Network POWERS (Peace, War and the World in European Security Challenges) co-funded by the Erasmus+ Programme of the European Union (see at http://powers-network.vsu.ru/en/home/). This publication reflects the views of the author, and the Commission cannot be held responsible for any use which may be made of the information contained therein.
} 
instance, the increased political and economic role of China and Russia in the region which might influence the relationship between the EU and the Western Balkans countries.

New political actors in the region have "heightened geopolitical competition" and pushed the EU to reaffirm that full EU membership for the Western Balkans "remains more than ever a geostrategic investment in a stable, strong and united Europe" (European Commission, $2020 \mathrm{a}, \mathrm{p} .1$ ). For the first time in the long history of European enlargements, the accession process is marked by a high geopolitical competitiveness with other global political actors. It is, therefore, not by chance that EU Institutions adopted several acts concerning this accession process to begin with the 2018 strategy for "a credible enlargement perspective for and enhanced EU engagement with the Western Balkans" (European Commission, 2018).

The European Commission (2018, pp. 1 and 18) clearly states that "the Western Balkans are part of Europe", their European future "is an investment in the EU's security, economic growth and influence" and "most fundamentally, leaders in the region must leave no doubt as to their strategic orientation and commitment [...] for making this historical opportunity a reality".

Credibility is the watchword for the Western Balkans which must be demonstrated by leaving no doubt as to their long-term political choices. Yet, credibility also requires credible efforts and reforms in crucial areas (e.g. rule of law, fundamental rights, governance) with delivery of tangible, everlasting and sustainable results. Finally, credibility also depends on overcoming the legacy of the past, establishing good neighbourly relations and "solving open issues well before their accession to the EU [because] the EU will not accept to import these disputes and the instability they could entail" (European Commission, 2018, pp. 7 and 3).

Credibility is also the watchword for the EU. It calls for enhanced engagement with the Western Balkans, made of new and/or strengthened actions and policies brought together by the Commission in a range of flagship initiatives aimed at better supporting comprehensive transformations and reforms in key crucial areas of common interest (rule of law, security and migration, socio-economic development, connectivity, digital agenda, reconciliation and good neighbourly relations).

\section{THE 2019 COMMISSION COMMUNICATION ON EU ENLARGEMENT POLICY}

The final Declaration of the EU-Western Balkans Summit held in May 2018 in Sofia reaffirmed the EU's "unequivocal support for the European perspective of the Western Balkans" and the recommitment of the Western Balkans "to the European perspective as their firm strategic choice [by way of a] clear public communication" (EU-Western Balkans Summit, 2018, §2).

The subsequent Commission Communication on EU Enlargement Policy tried to take advantage of the positive political momentum created by the Sofia Summit. With regard to Montenegro and Serbia (current frontrunners in the accession negotiations), the European Commission left open their "membership in a 2025 perspective" but urged them to "significantly step up efforts" in reforming the crucial areas of the rule of law and fundamental rights. In addition, the European Commission praised Albania and North 
Macedonia for having "embraced the opportunity and delivered on reforms" concrete and significant results (European Commission, 2019, pp. 1 and 11).

In particular, North Macedonia was praised for having "made great strides towards its strategic goal of EU and NATO integration" (North Macedonia eventually became a NATO member in 2020), "its determination to advance the EU reform agenda" and the "positive change in the mind-set" of national political actors as demonstrated by the 2019 Presidential elections held in a calm, peaceful and transparent manner (European Commission, 2019, pp. 14-15).

Albania was instead praised for its "good progress" and "continuous determination to advance on the EU agenda", notably in the implementation of justice reform and in the fight against organised crime and corruption (European Commission, 2019, p. 15).

In light of the progress achieved, the Commission thus recommended the opening of accession negotiations with Albania and North Macedonia. Yet, almost foreshadowing future problems, the Commission strongly underlined the urgent need for "Union's concrete and fast action [...] to lock in long-term positive momentum across the region" by opening the accession negotiations and, above all, the risk to damage its own credibility "throughout the region and beyond" and "help the EU's geopolitical competitors to root themselves on Europe's doorstep" in case of failure of rewarding the two countries for their progress (European Commission, 2019, p. 2).

With clear and eloquent words, the Commission highlighted the political crossroads to which EU Member States and institutions had reached in the enlargement process and warned about the dramatic consequences of making the wrong choice.

\section{THE FRENCH NON-PAPER ON THE REFORMED APPROACH TO THE EU ACCESSION PROCESS}

The European Commission's concerns proved to be justified a few weeks later with the adoption of its Communication on EU Enlargement policy.

At its June 2019 meeting, in fact, the Council did not endorse the Commission's recommendation on opening negotiations with Albania and North Macedonia in light of the limited time available and the importance of the matter and decided to revert to the issue no later than October 2019.

Unfortunately, at its October 2019 meeting the European Council decided to revert once again to the issue of enlargement before the EU-Western Balkans summit of May 2020. But most importantly the meeting highlighted deep divisions among the EU Member States on the opening of accession negotiations with the two countries. France vetoed the opening with both states (Denmark and Netherlands were against the opening only with Albania) for having not yet fully achieved the requested benchmarks (notwithstanding the different evaluation made by the Commission).

The deadlock at the European Council unleashed many criticisms.

As reported by the press (Rettman, 2019, pp. 2-3), in fact, Konrad Szymanski, Polish EU affairs minister, noted that "other countries - Russia and China [...] are just waiting for the EU to withdraw from this region". For his part, Micheal Roth, German EU affairs 
minister, urged the EU to keep its promises while a German diplomat warned that "much can be lost by creating a strategic vacuum" in the region. Finally, then-EU enlargement commissioner Johannes Hahn apologised to North Macedonian and Albanian citizens for the EU having failed to deliver on its promises due to a "certain trend that those who are already in the EU are a little reluctant to let others in".

A few weeks later France reaffirmed its "unequivocal support to the European perspective of the Western Balkans countries" and circulated a brief non-paper advocating for a "renewed approach to the accession process" to make it more effective, concrete and responsive. The core idea was to organize negotiations "on several successive stages, which would form coherent policy blocks" so as to enable gradual access of candidate countries to EU policies and programmes until full and complete accession (France Non-Paper, 2019, p. 1).

Accession negotiations would no longer be based on simultaneous opening of a large number of thematic chapters but on a few "policy blocks" or "stages". Only the completion of each stage would allow the candidate country "to move to the next stage [and] open up the possibility to participate in EU programmes, to be involved in certain sectoral policies and, where appropriate, to benefit from certain targeted finance" (France NonPaper, 2019, p. 2).

The "gradual association" would also require precise and detailed criteria linked to "easily and objectively verifiable indicators" (inspired by indicators set out by the EU and other international organizations) and stringent conditions to be effectively respected for moving from one stage to the next as well as tangible benefits and increased financial support to be provided by the EU and its Agencies (France Non-Paper, 2019, p. 2). French proposal was also grounded on the principle of reversibility ("whereby the candidate country, in whole or in part, no longer meets certain criteria or ceases to fulfil the commitments it has undertaken") and urged for a stronger political governance of the new process by Commission and Member States (France Non-Paper, 2019, pp. 2-3).

France proposed to organize the accession process in seven stages which would replace former corresponding chapters:

1) rule of law, fundamental rights, justice and security (once completed this stage, for instance, the candidate country would enter into cooperation agreements with Eurojust); 2) education, research and space, youth, culture, sports, environment, transport, telecommunications and energy (Erasmus+ and Horizon funds would then be available); 3) employment, social policy, health and consumer protection, competitiveness (once completed this stage, participation in the EU's industrial policy and/or involvement in important European projects would be possible); 4) economic and financial affairs (candidate country would then enter the banking union and the capital markets union); 5) internal market, agriculture and fisheries (access to the customs union and participation in the internal market); 6) foreign affairs (consular cooperation arrangements and possible involvement in defence programmes); 7) other matters (once completed this final stage, there would be full accession to the EU). 


\section{THE COMMUNICATION FROM THE COMMISSION ON THE REVISED METHODOLOGY FOR THE ACCESSION PROCESS OF THE WESTERN BALKAN COUNTRIES}

Vetoes casted against the opening of accession negotiations with Albania and North Macedonia and the French non-paper had the merit to urge EU institutions and Member States to rethink and revise the whole process so as to make it more credible, useful and effective.

The debate on pros and cons of the accession process resulted in the February 2020 Communication from the Commission (European Commission, 2020a) aimed at enhancing the accession process through a revised methodology guidelines and general principles of which are influenced by the French non-paper.

In its Communication the Commission (2020a, pp. 1-2) reaffirms some benchmarks of the EU's approach towards the Western Balkans (unequivocal support for their European perspective; a geostrategic investment especially at times of heightened geopolitical competition; the need "to tackle malign third country influence" in the region; etc.) but, at the same time, the Commission revises the methodology of the accession process in four key-areas in order to reinvigorate its credibility, political nature, dynamism, predictability and conditionality (2020a, pp. 2-6).

More credibility must "rest on solid trust, mutual confidence and clear commitments on both sides". Western Balkans leaders "must deliver more credibly on their commitment to implement the fundamental reforms required", while the EU must reward candidate countries by advancing the accession process once they have met established criteria and conditions. In a few words, for Western Balkan countries credibility means to implement long-term, structural and tangible reforms and, in particular, those in the fields of rule of law, functioning of democratic institutions, public administration, and economy (European Commission, 2020a, pp. 2-3).

A "stronger political steer" in the accession process requires "to put the political nature of the process front and centre and ensure stronger steering and high-level engagement from the Member States". It seems that the Commission wanted the EU Member States to take more responsibility and show the face after some of them vetoed against Albania and North Macedonia notwithstanding the Commission had expressly recommended the opposite. The Commission, in fact, underlines that the European future of the Western Balkans "is a significant political and not simply technical undertaking" for the EU Member States and urges them "to contribute more systematically to the accession process, including via monitoring on the ground through their experts, through direct contributions to the annual reports and through sectoral expertise" so that political dimension of the accession process would be primarily handled by the EU Member States while technical and procedural dimension by the Commission (European Commission, 2020a, p. 3).

For this reason the revised methodology provides for "high level political and policy dialogue with the countries, through regular EU-Western Balkans summits and intensified ministerial contacts" and includes the opportunity to let candidate countries participate as observers in key EU meetings. For the same reason the revised methodology provides for country-specific intergovernmental conferences based on the Commission's annual 
individual reports where EU Member States and candidate countries take stock of the overall accession process, discuss pros and cons of the situation of the candidate country and set out further developments and measures (European Commission, 2020a, pp. 3-4).

A "more dynamic process" essentially means that "the negotiating chapters will be organised in [six] thematic clusters" (European Commission, 2020a, p. 4). The influence of the seven "stages" proposed by the French non-paper is particularly evident, even though the French "gradual association" principle with its strict conditionality to move to the next stage is mitigated in the Commission's Communication.

The six thematic clusters outlined in the Annex to the Communication are as follows:

1) Fundamentals (gathering together several existing chapters such as, for instance, judiciary, fundamentals and justice, freedom and security); 2) Internal Market (free movement of goods, workers, services and capital; competition policy; company law; etc.); 3) Competitiveness and Inclusive Growth (information society and media; taxation; economic and monetary policy; etc.); 4) Green Agenda and Sustainable Connectivity (energy; transport policy; environment and climate change; trans-European networks); 5) Resources, Agriculture and Cohesion (agriculture and rural development; fisheries; etc.); 6) External Relations (external relations; foreign, security \& defence policy).

Main benefits resulting from the re-organization of the chapters in thematic clusters are to "allow a stronger focus on core sectors in the political dialogue" and to better identify "the most important and urgent reforms per sector". Accordingly, negotiations will be opened as a whole on each cluster rather than on an individual chapter basis (European Commission, 2020a, p. 4).

The thematic clusters' approach applies to recently opened negotiations with Albania and North Macedonia, while with Serbia and Montenegro the new approach is only an option to be applied within the existing negotiations frameworks and with the consent of these two countries.

Finally, a strengthened predictability and conditionality of the accession process requires, in terms of more predictability, "greater clarity on what the Union expects of enlargement countries at different stages of the process, and what the positive and negative consequences are of progress or lack thereof". To this end and still echoing the French non-paper, the Commission states the principle that conditions set for candidate countries "must be objective, precise, detailed, strict and verifiable". Also, the Commission expressly committed to "provide clearer guidance on specific reforms priorities and alignment criteria as well as expectations for next steps in the process" in its annual enlargement communications and reports so that candidate countries may be better aware of effective progress and failures on their way towards the accession (European Commission, 2020a, p. 5).

In terms of strategic communication to citizens and societies, an important side-effect is also to eliminate any uncertainty and ambiguity in the political dialogue between the $\mathrm{EU}$ and the Western Balkans and, therefore, to better counter the influence or propaganda of other political actors in the region.

Of course, predictability and conditionality are closely interlinked and conditionality must be clearer and more transparent as well. The enhanced conditionality is based on incentives ("clear and tangible" and "of direct interest to citizens") and negative measures (to 
be "more decisive" for sanctioning "any serious or prolonged stagnation or even backsliding in reform implementation and meeting the requirements of the accession process").

Incentives may consist both of "accelerated integration and 'phasing-in' to individual EU policies, the EU market and EU programmes" and of increased funding and investments on behalf of the EU. Instead, negative measures - informed by the Commission's annual report and proposed on its own or at motivated request of a Member State - are of many types in order to be adequately proportionated to the situation: a) put on hold in certain areas or overall suspension of the negotiations; b) re-opening or resetting of already closed chapters; c) decrease in EU funding; d) pausing or withdrawing access to EU programmes or other benefits coming from the phasing-in (European Commission, 2020a, pp. 5-6).

\section{THE OPENING OF NEGOTIATIONS WITH ALBANIA AND NORTH MACEDONIA AND THE ZAGREB DECLARATION}

Shortly after its Communication on enhancing the accession process, the Commission adopted two update reports on Albania (European Commission, 2020b) and North Macedonia (European Commission, 2020c) supplementing the 2019 yearly reports. The two documents updated and took note of further progress made in the latest period by both states in implementing fundamental reforms and fulfilling criteria and benchmarks set out by the EU.

The update on Albania underlined further advancing in the reform of judiciary system (new institutions for the self-governance of the judiciary were fully functional and effectively operating) and a proactive approach in the fight against corruption and organised crime (members of the Special Prosecution Office for Corruption and Organised Crime had been selected by the vetting institutions and had sworn). Police and judicial cooperation with the EU agencies and Member States law enforcement authorities had also increased and brought tangible results such as the creation of joint investigation teams, the conduct of successful large-scale law enforcement operations and the lowering of unfounded asylum application lodged by Albanian citizens to EU Member States (European Commission, 2020b, pp. 2-3 and 6-7).

The update on North Macedonia underlined the continuing progress on reforming public administration (i.e., adoption of the 2019-2021 Transparency Strategy), the continuing functioning of the reformed judiciary and the consolidation of the track record on investigating, prosecuting and trying corruption and organised crime cases (European Commission, 2020c, pp. 1-2 and 4).

On the basis of the updated reports of the Commission, at the meeting of 25 March 2020, the General Affairs Council endorsed the Commission Communication of 5 February 2020 (European Commission, 2020a) and decided to open accession negotiations with Albania and North Macedonia. The day after the European Council approved the revised enlargement methodology and the opening of negotiations without objections or vetoes.

The subsequent EU-Western Balkans Summit held in Zagreb on 6 May 2020 was therefore the first high-level meeting after the opening of negotiations with Albania and North Macedonia. The Zagreb Declaration recalls once again the unequivocal support for the 
European perspective of the Western Balkans and the need to "reinforce our cooperation on addressing disinformation and other hybrid activities originating in particular from third-state actors seeking to undermine the European perspective of the region". To this end the EU also urged a "public acknowledgment" of the Balkan leaders that support and cooperation provided by the EU "goes far beyond what any other partner has provided to the region” (EU-Western Balkans Summit, 2020, $\$ \$ 1,8$ and 5).

\section{THE JUNE 2020 COUNCIL CONCLUSIONS ON ENHANCING THE COOPERATION WITH WESTERN BALKANS PARTNERS IN THE FIELD OF MIGRATION AND SECURITY}

The Zagreb Declaration pays particular attention to security challenges and threats affecting both the EU and the Western Balkans (terrorism, extremism, corruption, organised crime, money laundering, migration, etc.). The need of strengthening the cooperation in these areas by taking advantage of EU legal and procedural tools and frameworks (to begin with the EU agencies operating in the field of justice and home affairs such as Europol, Eurojust, Frontex, and EASO) is therefore self-evident and pressing for the EU.

On 5 June 2020, therefore, the Council adopted its Conclusions on enhancing the cooperation with Western Balkans partners in the field of migration and security (Council of the European Union, 2020) and marked a milestone for future relationships between the EU and the Western Balkans.

The lengthy Conclusions set out several pledges and commitments for EU Member States and Western Balkans countries, the Commission and the EU agencies.

The Conclusions also identified a series of objectives to be achieved by the EU Member States together with Western Balkans partners such as: a) "to keep supporting the Western Balkans partners on migration and security issues [...] in order to [...] ensure that partners in the Western Balkans will be considered as safe third countries" (Council of the European Union, 2020, \$27); b) "to further explore possibilities for closer cooperation with CEPOL, Europol, EASO and [Frontex]" (Council of the European Union, 2020, \$28); c) "to step up the Western Balkans partners' participation [...] in Joint Investigation Teams (with the possible set up of joint EU-Western Balkans investigation teams) and Operational Task Forces (e.g. police investigation units, customs authorities, Asset Recovery Offices, Financial Investigation Units, border operations)" (Council of the European Union, 2020, $\$ 32$ ); d) "to make effective use of the I.C.P.O Interpol tools, and in particular the Stolen and Lost Travel Documents database, and actively share security-related information via the I-24/7 network" (Council of the European Union, 2020, $\$ 33$ ).

The European Commission, instead, is called: a) "to intensify [...] efforts to secure the conclusion [...] as well as efficient implementation of all status agreement with the Western Balkans partners, thereby facilitating the stepping up of operational cooperation between them and [Frontex]" (Council of the European Union, 2020, \$37); b) "to support the development by partners in the Western Balkans of interoperable national biometric registration/data-sharing systems on asylum applicants and irregular migrants [...] thus enabling regular regional information exchange and ensuring their future interoperability 
and compatibility with EU systems" (Council of the European Union, 2020, § 44).

The future (full) interoperability of national, EU (e.g. Visa Information System, Schengen Information System, European Criminal Records Information System, Entry/Exit System), and international (e.g. Interpol databases such as the Stolen and Lost Travel Documents and the Travel Documents Associated with Notices) information systems in the fields of police and judicial cooperation, asylum, migration, borders, and visas is the absolutely necessary condition to allow an efficient, effective and proactive integrated management of the EU external borders, address migratory and security challenges and threats, and prevent and combat transnational serious and organised crime. By adopting common standards, rules, and technical components (e.g. the future European search portal will be capable of querying simultaneously all relevant IT systems avoiding blind spots and different answers), in fact, interoperability allows to overcome certain structural shortcomings in the information management architecture (e.g. differently governed IT systems, information stored separately in unconnected systems, technical fragmentation) that leads to blind spots in queries on persons and objects.

The new approach to the management of data through interoperability ensures that "end-users, particularly border guards, law enforcement officers, immigration officials and judicial authorities have fast, seamless, systematic and controlled access to the information that they need to perform their tasks" (European Commission, 2017, p. 3) and does not require the collection of new data but only the best and more efficient consultation and utilization of existing data in the IT systems.

The EU is actively working on establishing the interoperability of IT systems within the EU and its Member States (two Regulations were adopted in 2019) but it is very telling for the European perspective of the Western Balkans countries that the EU would expressly envisage the future interoperability and compatibility with EU systems of their national databases on asylum and migration.

Finally, the June 2020 Council Conclusions call on relevant justice and home affairs EU agencies: a) to establish "interconnected national coordination centres for efficient migration policy, border management and tackling migration challenges" (Council of the European Union, 2020, $\$ 46$ ); b) "to step up the cooperation among the representative of the relevant JHA Agencies in the region, including their cooperation with local authorities" (e.g. by seconding officers and opening liaison office in the Western Balkans) (Council of the European Union, 2020, $₫ 47$ ); c) "to promote the exchange of information and knowledge [with] the Western Balkans partners [...] including by providing assistance for strengthening the capacity of border guards, police/other law enforcement, coast guards, migration, asylum and return authorities" (Council of the European Union, 2020, $\$ 49$ ).

\section{STEPPING UP THE COOPERATION WITH EU AGENCIES IN THE FIELD OF JUSTICE AND HOME AFFAIRS AS A KEY DRIVING FORCE FOR THE ACCESSION PROCESS OF THE WESTERN BALKANS}

The stepping up of the cooperation with EU agencies, foreshadowed by the Council Conclusions, starts from an already existing solid foundation. 
In recent years, Europol has concluded operational agreements to prevent and combat organised crime, terrorism, and other forms of international crime with Albania, Bosnia and Herzegovina, North Macedonia, Montenegro, and Serbia. These agreements mainly concern the exchange of information (including personal data and classified information) but they may be also extended to the exchange of specialist knowledge, general situation reports, information on criminal investigation procedures and crime prevention methods, strategic analysis, etc. In 2018, then Europol mobile offices were deployed in all the Western Balkans countries (except Montenegro) to support on-going investigations on migrant smuggling, drug trafficking, and document fraud. Europol mobile offices provide on-the-spot support, real-time access to SIENA (Europol's Secure Information Exchange Network Application) to quickly exchange of operational and strategic crime related data, forensic examinations, mobile device extraction kits, drug labs, etc. Moreover, since July 2019 Albania hosts Europol's first liaison office in the Western Balkans and this further highlights the importance of the Western Balkans countries as partners for Europol and the EU (the next two liaison offices will be opened in Bosnia and Herzegovina and Serbia).

Eurojust is stepping up the cooperation with the Western Balkans too.

In latest years Eurojust has concluded agreements on cooperation (concerning the exchange of information including personal data) with Albania (2019), Montenegro (2016), North Macedonia (2008), and Serbia (2019). It is also important to highlight the exchange of liaison prosecutors stationed at Eurojust and Montenegro, North Macedonia, and Serbia (by 2020 Albania will also exchange liaison prosecutors with Eurojust). Western Balkans countries are also increasingly involved in cross-border criminal investigations opened by the EU Member States: in 2019 Serbia has been requested to participate in 36 cases; Albania in 27 cases; North Macedonia in 16 cases; Montenegro in 9 cases.

Finally, Frontex (European Border and Coast Guard Agency) is closely cooperating with Western Balkans countries to improve control and management of EU external borders. Frontex provides technical and operational assistance and may also launch joint operations outside the EU by deploying officers and equipment and exchanging operational information, professional experiences, and best practices. It is noteworthy that in May 2019 the first joint operation ever launched abroad by Frontex was indeed in Albania (50 officers, 16 patrol cars and one thermo-vision van have been deployed from $12 \mathrm{EU}$ Member States to support Albania in border control and tackling cross-border crime). To launch joint operations Frontex must previously conclude an international agreement ("status agreement") with the third state. To date, Frontex has concluded status agreements with Albania (2019) and Montenegro (2020) while agreements with Bosnia and Herzegovina, North Macedonia, and Serbia are being finalized. Frontex has also concluded non-binding working arrangements with the competent authorities (usually, the Minister of Interior) of Albania, Bosnia and Herzegovina, Kosovo, Montenegro, North Macedonia, and Serbia to manage the operational cooperation and exchange unclassified information.

All these data further confirm both the strategic importance of the Western Balkans countries for the EU (and vice versa) in the field of justice and home affairs and the firm foundations on which cooperation and dialogue are being developed among all parties concerned. 
In our opinion, stepping up even more the cooperation in the field of justice and home affairs is absolutely needed not only for better tackling security challenges and threats but also for speeding up "from the bottom" the whole accession process of the Western Balkans countries.

The relevant EU agencies, in fact, may play a decisive role in the accession process and turn into a real game changer. Stronger and closer cooperation among the EU agencies, Member States and Western Balkans police and judicial authorities (including exchange of best practices and procedures, technical assistance, law enforcement training on operational matters, human rights and the rule of law) may inject into the accession process and "from the bottom" - that is, through dialogue and cooperation between equals (Western Balkans and European police and judicial authorities) - a strong amount of ethics, culture of compliance, and commitment to the rule of law. In fact, to further strengthen and develop these skills - that are fundamental to any judge, prosecutor, law enforcement officer and agent - may raise loyalty and awareness among the "servants of the State" and, as a result, may allow judiciary and police to fight against corruption and organised crime in more efficient and righteous way.

Western Balkans public and societies might be more positively impressed by tangible results achieved against corruption and organised crime through judiciary and police cooperation with the EU agencies than by strategic communication set "from above" (that is, from national and European politics) and focused on the fundamental values of the EU and the promotion of the European way of life in the wider world.

Of course, we are not calling into question the undisputed importance and centrality of the values enshrined in Article 2 of the TEU for the accession process of the Western Balkans. In a very pragmatic way, we are only wondering if a bottom-up approach (that is, enhanced training and cooperation with Western Balkans judiciary and police to strengthen ethics, compliance, and commitment to the rule of law) would not achieve the objective of promoting human rights and the rule of law better than a top-down approach (that is, strategic communication from EU institutions, national governments, and political parties).

We believe that helping to make more efficient and credible police and judicial authorities would be the best "business card" for the EU before the citizens of the Western Balkans countries. In fact, there may be a risk that a strategic communication based on EU fundamental values and principles might be perceived (albeit wrongly) by the public as something "out there", that is, away from everyday life's problems. Instead, positive and tangible results in the fight against corruption and organised crime due to the strengthening of skills and capacity of police and judicial authorities might better unveil to the public the deepest and more practical meaning of an "European perspective" for the region based on the respect for human rights and the upholding of the rule of law.

As a result, the accession process might gather more support from the public and be reinvigorated, while the future European perspective might become more credible and dynamic for all layers of the Western Balkans societies. 


\section{LIST OF REFERENCES}

Council of the European Union 2020. Council Conclusions on enhancing cooperation with Western Balkans partners in the field of migration and security, Brussels, 5 June $2020,8622 / 20$

EU-Western Balkans Summit 2018. EU-Western Balkans Sofia Summit, Sofia Declaration, 17 May 2018

EU-Western Balkans Summit 2020. EU-Western Balkans Zagreb Summit, Zagreb Declaration, 6 May 2020

European Commission 2017. European Commission, Proposal for a Regulation of the European Parliament and of the Council on establishing a framework for interoperability between EU information systems (borders and visa) and amending Council Decision 2004/512/EC, Regulation (EC) No 767/2008, Council Decision 2008/633/JHA, Regulation (EU) 2016/399 and Regulation (EU) 2017/2226, Strasbourg, 12.12.2017, COM(2017) 793 final

European Commission 2018. European Commission, Communication from the Commission to the European Parliament, the Council, the European Economic and Social Committee and the Committee of the Regions. A credible enlargement perspective for and enhanced EU engagement with the Western Balkans, Strasbourg, 6.2.2018, COM(2018) 65 final

European Commission 2019. European Commission, Communication from the Commission to the European Parliament, the Council, the European Economic and Social Committee and the Committee of the Regions. 2019 Communication on EU Enlargement Policy, Brussels, 29.5.2019, COM(2019) 260 final

European Commission 2020a. European Commission, Communication from the Commission to the European Parliament, the Council, the European Economic and Social Committee and the Committee of the Regions. Enhancing the accession process - A credible EU perspective for the Western Balkans, Brussels, 5.2.2020, COM(2020) 57 final

European Commission 2020b. European Commission, Commission Staff Working Document. Update on the Republic of Albania, Brussels, 2.3.2020, SWD(2020) 46 final

European Commission 2020c. European Commission, Commission Staff Working Document. Update on the Republic of North Macedonia, Brussels, 2.3.2020, SWD(2020) 47 final

France Non-Paper 2019. Non-Paper. Reforming the European Union accession process, November 2019. Available at https://www.politico.eu/wp-content/uploads/2019/11/ Enlargement-nonpaper.pdf (7.7.2020)

Rettman 2019. Rettman, A. 16 October 2019. Balkans row to hit EU summit after French veto. Available at https://euobserver.com/enlargement/146287 (7.7.2020) 